\title{
Sistem Pendukung Keputusan Penentuan Pemberian Insentif Pegawai THL Menggunakan Metode Promethee Pada Kantor Walikota Pematangsiantar
}

\author{
Jaka Sepridho*, Irfan Sudahri Damanik, Harly Okprana \\ Prodi Sistem Informasi, STIKOM Tunas Bangsa, Pematangsiantar, Indonesia \\ Email: 1,*jakasepridho16s04@gmail.com, 2irfansudahri@ amiktunasbangsa.ac.id, ${ }^{3}$ harly@ amiktunasbangsa.ac.id \\ Submitted: 21/02/2021; Accepted: 14/03/2021; Published: 30/05/2021
}

\begin{abstract}
Abstrak-Kantor Walikota Pematangsiantar merupakan sebuah lembaga yang digunakan dan berfungsi untuk melayani dan mengayomi masyarakat. Penulisan ini mengusulkan sebuah penelitian sistem pendukung keputusan menggunakan metode Promethee. Promethee adalah satu dari beberapa metode penentuan urutan atau prioritas dalam analisis multikriteria. Penulisan ini menggunakan metode Promethee sebagai langkah dalam menentukan pemberian insentif kepada Pegawai Tenaga Harian Lepas di Kantor Walikota Pematangsiantar. Dalam penelitian ini penulis mengambil 10 alternatif dengan 5 kriteria penilaian diantaranya absen kehadiran, prestasi, perilaku, riwayat lama bekerja dan kerja sama tim. Dengan hasil tertinggi didapatkan oleh alternatif 9 atas nama Triono dengan nilai 0,422 dan hasil terendah didapatkan oleh alternatif 6 atas nama Soraya dengan nilai $-0,211$.
\end{abstract}

Kata Kunci: Sistem Pendukung Keputusan; Promethee; Insentif; Pegawai THL; Kantor Walikota

\begin{abstract}
Pematangsiantar Mayor Office is an institution that is used and functions to serve and protect the community. This paper proposes a decision support system research using the Promethee method. Promethee is one of several methods of determining the order or priority in multi-criteria analysis. This writing uses the Promethee method as a step in determining the provision of incentives for freelance daily staff at the Pematangsiantar Mayor's Office. In this study the authors took 10 alternatives with 5 assessment criteria including absenteeism, achievement, behavior, long history of work and teamwork. With the highest result obtained by alternative 9 on behalf of Triono with a value of 0.422 and the lowest result obtained by alternative 6 on behalf of Soraya with a value of -0.211
\end{abstract}

Keywords: Decision Support Systems; Promethee; Incentives; Employees of THL; Mayor's Office

\section{PENDAHULUAN}

Dalam era globalisasi, dunia informasi berkembang begitu pesat karena ditunjang dengan perkembangan teknologi yang semakin canggih. Komputer merupakan salah satu alat guna menunjang perkembangan teknologi informasi. Sehingga suatu lembaga atau instansi yang menggunakan komputer dalam mengelolah sistem informasinya akan mempunyai nilai lebih daripada sistem yang diolah secara manual. Dapat dikatakan sistem informasi yang menggunakan komputer akan menunjang efisiensi dan produktivitas yang tinggi.

Dalam setiap perusahaan, instansi, organisasi atau badan usaha akan memberikan gaji sebagai kompensasi dari kinerja seorang pegawai. Hal ini dikarenakan pegawai merupakan salah satu sumber daya yang digunakan sebagai alat penggerak dalam memajukan suatu perusahaan[1].

Sumber daya manusia (SDM) dalam sebuah perusahaan merupakan hal yang krusial untuk dikelola dengan baik. Hal tersebut dikarenakan dengan sumber daya yang baik, maka roda perusahaan akan berjalan dengan baik pula. SDM atau pegawai harus dikelola agar dapat memberikan hasil terbaik dan loyalitas yang tinggi pada perusahaan tempat mereka bekerja. Selain memberikan pelatihan dan motivasi, pegawai juga perlu diberikan apresiasi terhadap apa yang telah mereka upayakan dan kerjakan selama bekerja diperusahaan. Setiap pegawai biasanya mendapatkan gaji dari perusahaan tempat bekerja. Selain gaji, bonus gaji biasanya juga akan diperoleh pegawai dengan mempertimbangkan kinerja yang telah dilakukan[2].

THL merupakan kebijaksanaan Pemerintah daerah (PEMDA) sesuai dengan Hak Otonomi yang dimiliki, sehingga akan berusaha memperoleh Sumber Daya Manusia ( SDM ) yang trampil, profesional dan mandiri serta mempunyai etos kerja yang tinggi[3]

Untuk menghindari unsur subyektifitas dalam pemberian insentif atau bonus gaji kepada Pegawai THL, maka penulis mencoba mengimplementasian suatu sistem pendukung keputusan yang terdapat dalam Promethee yang mampu membantu dalam penentuan Pegawai THL yang berhak menerima insentif. Sistem pendukung keputusan adalah sistem yang interaktif mendukung proses pengambilan keputusan individu maupun kelompok dalam kehidupan masyarakat, organisasi, swasta maupun badan lain.

Pada suatu studi kasus yang menggunakan Promethee menunjukkan adanya perbaikan dalam membuatan keputusan sebagai preferensi pembuat keputusan. Metode ini mudah dipahami oleh pembuat keputusan karena kesederhanaannya dan konsistensi[4].

Promethee adalah suatu metode penentuan urutan (prioritas) dalam analisis multikriteria. Masalah pokoknya adalah kesederhanaan, kejelasan, dan kestabilan. Dugaan dari dominasi kriteria yang digunakan dalam Promethee adalah penggunaan nilai dalam hubungan outranking. Metode ini termasuk metode peringkat yang cukup sederhana dalam konsep dan aplikasi dibandingkan dengan metode lain untuk analisis multikriteria[5] 
Penelitian sebelumnya yang telah dilakukan pada tahun 2018 menggunakan metode Promethee tipe preferensi yang digunakan adalah Usual Criterion untuk menentukan Prioritas Penerima Kredit pada kantor Mega Finance cabang Solo. Penelitian ini menggunakan 5 alternatif dan 7 kriteria dengan kesimpulan yang diperoleh adalah metode Promethee memiliki tingkat akurasi yang sangat baik yaitu nilai akurasi mencapai 99,9\% dan error rate $0,1 \%[4]$.

Pada tahun yang sama, yaitu 2018 juga telah dilakukan penelitian menggunakan metode Promethee dalam menganalisa Rekomendasi Bank Konvensional sebagai solusi cerdas untuk menabung.penelitian ini menggunakan 5 alternatif dan 5 kriteria dengan kesimpulan yang diperoleh dalam penelitian ini adalah sistem pendukung keputusan dengan metode Promethee ini dapat membantu Calon Nasabah dalam menetukan tempat untuk menabung dengan memberikan rekomendasi dari beberapa alternatif yang diberikan serta penambahan kriteria penilaian untuk setiap alternatif dapat mempengaruhi penilaian dan hasil perhitungan metode promethee[6].

Pada tahun 2020 terdapat salah satu penelitian yang menggunakan metode Promethee II untuk menentukan jenis Pohon Pelindung yang akan ditanam di pinggir jalan. Penelitian ini menggunakan 6 alternatif dan 4 kriteria dengan kesimpulan yang diperoleh dalam penelitian tersebut adalah sistem yang dibangun mampu membantu memberikan data sebagai bahan pertimbangan bersifat akurat dan lebih efesien[7].

Dan penelitian terakhir yang penulis kutip adalah penelitian yang baru saja dilakukan pada Januari 2021 lalu. Penelitian menggunakan metode Promethee II untuk menentukan Karyawan Terbaik pada Pusat Penelitian Kelapa Sawit Area Medan. Penelitian ini menggunakan 10 alternatif dan 4 kriteria dengan kesimpulan yang diperoleh adalah penerapan metode Promethee II sangat efisien digunakan sebagai cara untuk pemilihan Karyawan Terbaik yang pantas dan layak untuk mendapatkan hadiah liburan keluar Negeri karena langkah-langkah penyelesaiannya cukup sederhana[8].

Dengan merujuk pada hasil penelitian sebelumnya dan beberapa penjelasan singkat tentang metode Promethee maka dipilihlah metode Promethee yang diharapkan dapat menghasilkan sistem pendukung keputusan yang mampu menyelesaikan masalah usulan Pegawai THL yang berhak menerima insentif pada Kantor Walikota Pematangsiantar.

\section{METODE PENELITIAN}

\subsection{Metode Pengumpulan Data}

Pengumpulan data merupakan proses pengadaan data primer, untuk kebutuhan suatu penelitian. Adapun teknik pengumpulan data dalam penelitian ini yaitu :

a. Metode Observasi

Pada tahap ini penulis melakukan Praktik Kerja di Kantor Walikota Pematangsiantar.

b. Metode Kajian Literatur

Pada tahap ini penulis berkunjung ke Perpustakaan STIKOM Tunas Bangsa Pematangsiantar untuk mencari buku dan penelitian terdahulu yang terkait dengan judul terkait.

c. Metode Wawancara

Pada tahap ini Penulis melakukan tanya jawab seputar data terkait seperti kriteria penilaian dalam pemberian insentif serta data pegawai Tenaga Harian Lepas yang masuk dalam penelitian ini.

\subsection{Sistem Pendukung Keputusan}

Sistem pendukung keputusan atau decision support sistem (DSS) merupakan sistem informasi interakif yang menyediakan informasi, pemodelan, dan pemanipulasian data. Sistem Pendukung Keputusan biasanya dibangun untuk mendukung solusi atas suatu masalah atau untuk mengevaluasi suatu peluang. Sistem Pendukung Keputusan yang seperti itu disebut dengan Aplikasi DSS. Sistem pendukung keputusan digunakan untuk menyelesaikan masalah yang tidak terstruktur. Pada dasarnya sistem pendukung keputusan dirancang untuk mendukung seluruh tahap pengambilan keputusan[9]. Sistem Pendukung Keputusan adalah bagian dari sistem informasi berbasis komputer yang dipakai untuk mendukung pengambilan keputusan dalam suatu organisasi atau perusahaan. Dapat juga dikatakan sebagai sistem komputer yang mengolah data menjadi informasi untuk mengambil keputusan dari masalah semi terstruktur yang spesifik[10], [11].

\subsection{Metode Promethee}

Multi-criteria Decision Making (MCDM) menjadi salah satu riset operasional yang berkembang paling cepat selama dua dekade terakhir. Teori MCDM sendiri dapat dibagi menjadi Multi Objective Decision Making (MODM) dan Multi Attribute Decision Making (MADM). MODM menganalisa subset dari ruang vektor secara berkelanjutan, yang biasanya dibatasi oleh batasan-batasan, dengan mengalokasi semua solusi yang efisien, sebelum menentukan nilai optimum berdasarkan pada pilihan pengguna (user). Oleh karena itu, MODM memungkinkan untuk digunakan dalam perencanaan operasional, semisal pemrograman tujuan[8].

Metode Promethee merupakan salah satu teknik perhitungan Multi Criteria Decision Making (MCDM) yang dikembangkan oleh Brans dan Vincke pada tahun 1985[7]. Promethee adalah satu dari beberapa metode 
penentuan urutan atau prioritas dalam analisis multikriteria. Metode ini dikenal sebagai metode yang efisien dan simple, tetapi juga yang mudah diterapkan dibanding dengan metode lain untuk menuntaskan masalah multikriteria. Metode ini mampu mengakomodir kriteria pemilihan yang bersifat kuantitatif dan kualitatif[12].

Langkah-langkah perhitungan dengan metode promethee adalah sebagai berikut:

a. Menentukan beberapa alternatif.

b. Menentukan beberapa kriteria dan bobot penilaian.

c. Menentukan rating kecocokan alternatif setiap alternatif terhadap kriteria.

d. Menentukan tipe penilaian, dimana tipe penilaian memiliki 2 tipe yaitu; tipe minimum dan maksimum.

e. Menentukan tipe preferensi untuk setiap kriteria yang paling cocok didasarkan pada data dan pertimbangan dari decision maker. Tipe preferensi ini berjumlah Enam (Usual, Quasi, Linear, Level, Linear Quasi dan Gaussian).

f. Menghitung nilai preferensi serta menentukan nilai preferensi berdasarkan tipe preferensi yang telah dipilih sebelumnya.

g. Mencari Nilai Indeks Preferensi Multikriteria.

h. Menghitung nilai Entering Flow dan Leaving Flow.

i. Menghitung nilai Net Flow.

j. Hasil pengurutan hasil dari perangkingan.

Dalam Promethee terdapat enam bentuk fungsi preferensi kriteria. Hal ini tentu saja tidak mutlak, tetapi bentuk ini cukup baik untuk beberapa kasus. Untuk memberikan gambaran yang lebih baik terhadap area yang tidak sama, digunakan fungsi selisih nilai kriteria antara alternative $\mathrm{H}(\mathrm{d})$ dimana hal ini mempunyai hubungan langsung pada fungsi preferensi. Adapun enam fungsi prefrensi yang terdapat dalam metode promethee adalah sebagai berikut[6]:

a. Kriteria Usual

$$
H(d)=\left\{\begin{array}{l}
0 \text { jika } d \leq 0 \\
1 \text { jika } d>0
\end{array}\right.
$$

Dimana:

$\mathrm{H}(\mathrm{d})=$ fungsi selisih kriteria antar alternative

$\mathrm{d}=$ selisih nilai kriteria $\{\mathrm{d}=\mathrm{f}(\mathrm{a})-\mathrm{f}(\mathrm{b})\}$

b. Kriteria Quasi (Quasi Criterion /U-Shape)

$H(d)=\left\{\begin{array}{l}0 \text { jika } d \leq q \\ 1 \text { jika } d>q\end{array}\right.$

Dimana:

$\mathrm{H}(\mathrm{d})=$ fungsi selisih kriteria antar alternative

$\mathrm{d}=$ selisih nilai kriteria $\{\mathrm{d}=\mathrm{f}(\mathrm{a})-\mathrm{f}(\mathrm{b})\}$

$\mathrm{q}=$ harus merupakan nilai tetap

c. Kriteria Linier (Linier Criterion / V-Shape)

$H(d)=\left\{\begin{array}{c}0 \text { jika } d \leq 0 \\ \frac{d}{p} \text { Jika } 0 \leq d \leq p \\ 1 \text { Jika } d>p\end{array}\right.$

Dimana:

$\mathrm{H}(\mathrm{d})=$ fungsi selisih kriteria antar alternative

$\mathrm{d}=$ selisih nilai kriteria $\{\mathrm{d}=\mathrm{f}(\mathrm{a})-\mathrm{f}(\mathrm{b})\}$

$\mathrm{p}=$ nilai kecenderungan atas

d. Kriteria Level (Level Criterion)

$H(d)=\left\{\begin{array}{c}0 \text { jika } d \leq q \\ 0,5 \text { Jika } q<d \leq p \\ 1 \text { Jika } d>p\end{array}\right.$

Dimana:

$\mathrm{H}(\mathrm{d})=$ fungsi selisih kriteria antar alternative

$\mathrm{d}=$ selisih nilai kriteria $\{\mathrm{d}=\mathrm{f}(\mathrm{a})-\mathrm{f}(\mathrm{b})\}$

$\mathrm{p}=$ nilai kecenderungan atas

$\mathrm{q}=$ harus merupakan nilai tetap

e. Kriteria dengan Preferensi Linier dan Area yang Tidak Berbeda

$H(d)=\left\{\begin{array}{c}0 \text { jika } d \leq q \\ \frac{d-q}{p-q} \text { Jika } q \leq d \leq p \\ 1 \text { Jika } d>p\end{array}\right.$

Dimana:

$\mathrm{H}(\mathrm{d})=$ fungsi selisih kriteria antar alternative 
$\mathrm{d}=$ selisih nilai kriteria $\{\mathrm{d}=\mathrm{f}(\mathrm{a})-\mathrm{f}(\mathrm{b})\}$

$\mathrm{p}=$ nilai kecenderungan atas

$\mathrm{q}=$ harus merupakan nilai tetap

f. Kriteria Gaussian (Gaussian Criterion)

$$
H(d)=\left\{\begin{array}{c}
0 \text { jika } d \leq 0 \\
1-e-\frac{d^{2}}{2 a^{2}} \text { jika } d>0
\end{array}\right.
$$

Dimana:

$\mathrm{H}(\mathrm{d})=$ fungsi selisih kriteria antar alternative

$\mathrm{d}=$ selisih nilai kriteria $\{\mathrm{d}=\mathrm{f}(\mathrm{a})-\mathrm{f}(\mathrm{b})\}$

Selain disajikannya enam fungsi prefrensi, perangkingan metode prometee juga terdiri dari tiga bentuk perangkingan yaitu :

a. Leaving Flow

$\varphi^{+}(a)=\frac{1}{n-1} \sum x \in A \varphi(a, x)$

Leaving flow, digunakan untuk menentukan urutan prioritas pada proses promethee yang menggunakan urutan parsial.

b. Entering flow

$$
\varphi^{-}(a)=\frac{1}{n-1} \sum x \in A \varphi(a, x)
$$

Entering flow, digunakan untuk menentukan urutan prioritas pada proses promethee yang menggunakan urutan parsial.

c. Net flow

$\varphi(a)=\varphi^{+}(a)-\varphi^{-}(a)$

Net flow, digunakan untuk menghasilkan keputusan akhir penentuan ururan dalam menyelesaikan masalah sehingga menghasilkan urutan lengkap.

\section{HASIL DAN PEMBAHASAN}

Dalam menentukan Pegawai THL yang akan mendapatkan insentif, beberapa alternatif akan dijadikan sebagai pertimbangan. Dengan penerapan sistem pendukung keputusan dapat membantu menghasilkan alternatif dan kriteria yang tepat sesuai dengan kebutuhan. Data yang diperoleh kemudian diolah dengan menggunakan metode Promethee. Data Kriteria didapat dari pendekatan subjektif yaitu nilai bobot ditentukan berdasarkan subjektifitas dari para pengambil keputusan yaitu dalam hal ini khususnya yaitu Pimpinan Kantor Walikota Pematangsiantar.

Tabel 1. Data Penelitian

\begin{tabular}{clccccc}
\hline & & \multicolumn{5}{c}{ Kriteria } \\
\cline { 3 - 6 } No & Alternatif & $\begin{array}{c}\text { Absen } \\
\text { Kehadiran }\end{array}$ & Prestasi & Prilaku & Lama Bekerja & $\begin{array}{c}\text { Kerja Sama } \\
\text { Tim }\end{array}$ \\
\hline 1. & Suparman & $7 \mathrm{x}$ & $2 \mathrm{x}$ & 90 & 2 Tahun & 90 \\
2. & Anto & $5 \mathrm{x}$ & $3 \mathrm{x}$ & 75 & 10 Tahun & 70 \\
3. & Safii & $2 \mathrm{x}$ & $4 \mathrm{x}$ & 65 & 5 Tahun & 75 \\
4. & Rasid & $8 \mathrm{x}$ & $6 \mathrm{x}$ & 95 & 3 Tahun & 80 \\
5. & Niko & $2 \mathrm{x}$ & $10 \mathrm{x}$ & 60 & 6 Tahun & 90 \\
6. & Herman & $1 \mathrm{x}$ & $2 \mathrm{x}$ & 50 & 7 Tahun & 75 \\
7. & Rani & $2 \mathrm{x}$ & $4 \mathrm{x}$ & 65 & 5 Tahun & 75 \\
8. & Safira & $8 \mathrm{x}$ & $6 \mathrm{x}$ & 95 & 3 Tahun & 80 \\
9. & Triono & $2 \mathrm{x}$ & $10 \mathrm{x}$ & 60 & 6 Tahun & 90 \\
10. & Soraya & $1 \mathrm{x}$ & $2 \mathrm{x}$ & 50 & 7 Tahun & 75 \\
\hline
\end{tabular}

\subsection{Data Alternatif}

Data alternatif berperan penting dalam proses pemilihan Pegawai THL yang akan mendapatkan insentif. Alternatif yang dipilih merupakan alternatif yang direkomendasikan oleh pihak Kantor Walikota Pematangsiantar agar data tersebut lebih akurat dan terpercaya. Beberapa alternatif-alternatif yang dimaksud dapat dilihat pada tabel 2 berikut.

Tabel 2. Data Alternatif

\begin{tabular}{ccc}
\hline No & & Alternatif \\
\hline 1. & $\mathrm{~A}_{1}$ & Suparman \\
2. & $\mathrm{~A}_{2}$ & Anto
\end{tabular}

\begin{tabular}{ccc}
\hline No & & Alternatif \\
\hline 6. & $\mathrm{~A}_{6}$ & Herman \\
7. & $\mathrm{~A}_{7}$ & Rani
\end{tabular}




\begin{tabular}{ccc}
\hline No & & Alternatif \\
\hline 3. & $\mathrm{~A}_{3}$ & Safii \\
4. & $\mathrm{~A}_{4}$ & Rasid \\
5. & $\mathrm{~A}_{5}$ & Niko \\
\hline
\end{tabular}

\begin{tabular}{ccc}
\hline No & & Alternatif \\
\hline 8. & $\mathrm{~A}_{8}$ & Safira \\
9. & $\mathrm{~A}_{9}$ & Triono \\
10. & $\mathrm{~A}_{10}$ & Soraya \\
\hline
\end{tabular}

\subsection{Data Kriteria}

Dalam proses metode Promethee memerlukan kriteria-kriteria yang akan dijadikan bahan perhitungan dan pertimbangan untuk mencapai perangkingan dalam menentukan Pegawai THL yang berhak menerima insentif di Kantor Walikota Pematangsiantar. Adapun kriteria-kriteria yang menjadi bahan perhitungan dan pertimbangan dapat dilihat pada tabel 3 .

Tabel 3. Data Kriteria

\begin{tabular}{cll}
\hline No & & \multicolumn{1}{c}{ Kriteria } \\
\hline 1. & $\mathrm{C}_{1}$ & Absen Kehadiran \\
2. & $\mathrm{C}_{2}$ & Prestasi \\
3. & $\mathrm{C}_{3}$ & Perilaku \\
4. & $\mathrm{C}_{4}$ & Riwayat Lama Bekerja \\
5. & $\mathrm{C}_{5}$ & Kerja Sama Tim \\
\hline
\end{tabular}

\subsection{Data Bobot}

Berikutnya kriteria di atas masing-masing akan ditentukan bobotnya. Berikut daftar tabel setiap kriteria dan nilai bobot yang sudah ditentukan.

Tabel 4. Kriteria Absen Kehadiran $\left(\mathrm{C}_{1}\right)$

\begin{tabular}{ccc}
\hline Range & Keterangan & Nilai \\
\hline 0 & Sangat baik & 100 \\
$1-3$ & Baik & 75 \\
$4-6$ & Kurang & 50 \\
$>=7$ & Buruk & 25 \\
\hline
\end{tabular}

Tabel 5. Kriteria Prestasi $\left(\mathrm{C}_{2}\right)$

\begin{tabular}{ccc}
\hline Range & Keterangan & Nilai \\
\hline$>=10$ & Sangat baik & 100 \\
$7-9$ & Baik & 75 \\
$4-6$ & Kurang & 50 \\
$<=3$ & Buruk & 25 \\
\hline
\end{tabular}

Tabel 6. Kriteria Perilaku $\left(\mathrm{C}_{3}\right)$

\begin{tabular}{ccc}
\hline Range & Keterangan & Nilai \\
\hline$>=90$ & Sangat baik & 100 \\
$60-89$ & Baik & 75 \\
$40-59$ & Kurang & 50 \\
$<=40$ & Buruk & 25 \\
\hline
\end{tabular}

Tabel 7. Kriteria Riwayat Lama Bekerja $\left(\mathrm{C}_{4}\right)$

\begin{tabular}{ccc}
\hline Range & Keterangan & Nilai \\
\hline$>=10$ & Sangat baik & 100 \\
$7-9$ & Baik & 75 \\
$3-6$ & Kurang & 50 \\
$<=3$ & Buruk & 25 \\
\hline
\end{tabular}

Tabel 8. Kriteria Kerja Sama Tim $\left(\mathrm{C}_{5}\right)$

\begin{tabular}{ccc}
\hline Range & Keterangan & Nilai \\
\hline$>=10$ & Sangat baik & 100 \\
$7-9$ & Baik & 75 \\
$3-6$ & Kurang & 50 \\
$<=3$ & Buruk & 25 \\
\hline
\end{tabular}

Berdasarkan kriteria di atas, maka rating kecocokan yang diperoleh adalah sebagai berikut: 
Tabel 9. Rating Kecocokan Setiap Alternatif

\begin{tabular}{clccccc}
\hline \multirow{2}{*}{ No } & Alternatif & \multicolumn{5}{c}{ Kriteria } \\
\cline { 3 - 6 } & & $\begin{array}{c}\text { Absen } \\
\text { Kehadiran }\end{array}$ & Prestasi & Prilaku & Lama Bekerja & $\begin{array}{c}\text { Kerja Sama } \\
\text { Tim }\end{array}$ \\
\hline 1 & Suparman & 25 & 25 & 100 & 25 & 100 \\
2 & Anto & 50 & 25 & 75 & 100 & 75 \\
3 & Safii & 75 & 50 & 75 & 50 & 75 \\
4 & Rasid & 25 & 50 & 100 & 25 & 75 \\
5 & Niko & 75 & 100 & 75 & 50 & 100 \\
6 & Herman & 75 & 25 & 50 & 75 & 75 \\
7 & Rani & 75 & 50 & 75 & 50 & 75 \\
8 & Safira & 25 & 50 & 100 & 25 & 75 \\
9 & Triono & 75 & 100 & 75 & 50 & 100 \\
10 & Soraya & 75 & 25 & 50 & 75 & 75 \\
\hline
\end{tabular}

\subsection{Penerapan Metode Promethee}

Selanjutnya masuk kedalam tahap pengolahan data menggunakan metode promethee.

\subsubsection{Menentukan Tipe Preferensi}

Pada penelitian ini tipe prefrensi yang digunakan adalah tipe pertama (Tipe Usual) dengan persamaan sebagai berikut:

$H(d)=\left\{\begin{array}{l}0 \text { jika } d \leq 0 \\ 1 \text { jika } d>0\end{array}\right.$

Dimana:

$\mathrm{H}(\mathrm{d})$ = fungsi selisih kriteria antar alternatif $\mathrm{d}=$ selisih nilai kriteria $\{\mathrm{d}=\mathrm{f}(\mathrm{a})-\mathrm{f}(\mathrm{b})\}$

\subsubsection{Menghitung Nilai Prefrensi}

Setelah menentukan tipe yang digunakan selanjutnya masuk ke dalam tahap menghitung nilai prefrensi dengan membandingkan setiap alternatif yang ada.

a. Absensi Kehadiran $\left(\mathrm{C}_{1}\right)$

$\begin{array}{ll}\mathrm{A}_{1}, \mathrm{~A}_{2}=25-50=-25 & \mathrm{~A}_{2}, \mathrm{~A} 3=50-75=-25 \\ \mathrm{~A}_{2}, \mathrm{~A}_{1}=50-25=25 & \mathrm{~A}_{3}, \mathrm{~A}_{2}=75-50=25 \\ \mathrm{~A}_{1}, \mathrm{~A}_{3}=25-75=-50 & \mathrm{~A}_{2}, \mathrm{~A}_{4}=50-25=25 \\ \mathrm{~A}_{3}, \mathrm{~A}_{1}=75-25=50 & \mathrm{~A}_{4}, \mathrm{~A}_{2}=25-50=-25 \\ \mathrm{~A}_{1}, \mathrm{~A}_{4}=25-25=0 & \mathrm{~A}_{2}, \mathrm{~A}_{5}=50-75=-25 \\ \mathrm{~A}_{4}, \mathrm{~A}_{1}=25-25=0 & \mathrm{~A}_{5}, \mathrm{~A}_{2}=75-50=25 \\ \mathrm{~A}_{1}, \mathrm{~A}_{5}=25-75=-50 & \mathrm{~A}_{2}, \mathrm{~A}_{6}=50-75=-25 \\ \mathrm{~A}_{5}, \mathrm{~A}_{1}=75-25=50 & \mathrm{~A}_{6}, \mathrm{~A}_{2}=75-50=25 \\ \mathrm{~A}_{1}, \mathrm{~A}_{6}=25-75=-50 & \mathrm{~A}_{2}, \mathrm{~A}_{7}=50-75=-25 \\ \mathrm{~A}_{6}, \mathrm{~A}_{1}=75-25=50 & \mathrm{~A}_{7}, \mathrm{~A}_{2}=75-50=25 \\ \mathrm{~A}_{1}, \mathrm{~A}_{7}=25-75=-50 & \mathrm{~A}_{2}, \mathrm{~A}_{8}=50-25=25 \\ \mathrm{~A}_{7}, \mathrm{~A}_{1}=75-25=50 & \mathrm{~A}_{8}, \mathrm{~A}_{2}=25-50=-25 \\ \mathrm{~A}_{1}, \mathrm{~A}_{8}=25-25=0 & \mathrm{~A}_{2}, \mathrm{~A}_{9}=50-75=-25 \\ \mathrm{~A}_{8}, \mathrm{~A}_{1}=25-25=0 & \mathrm{~A}_{9}, \mathrm{~A}_{2}=75-50=25 \\ \mathrm{~A}_{1}, \mathrm{~A}_{9}=25-75=-50 & \mathrm{~A}_{2}, \mathrm{~A}_{10}=25-75=-50 \\ \mathrm{~A}_{9}, \mathrm{~A}_{1}=75-25=50 & \mathrm{~A}_{10}, \mathrm{~A}_{2}=75-25=50 \\ \mathrm{~A}_{1}, \mathrm{~A}_{1}=25-75=-50 & \end{array}$

$\mathrm{A} 3, \mathrm{~A} 4=75-25=50$

$\mathrm{A}_{4}, \mathrm{~A}_{3}=25-75=-50$

$\mathrm{A}_{3}, \mathrm{~A}_{5}=75-75=0$

$\mathrm{A}_{5}, \mathrm{~A}_{3}=75-75=0$

$\mathrm{A}_{3}, \mathrm{~A}_{6}=75-75=0$

$\mathrm{A}_{6}, \mathrm{~A}_{3}=75-75=0$

$\mathrm{A}_{3}, \mathrm{~A}_{7}=75-75=0$

$\mathrm{A}_{7}, \mathrm{~A}_{3}=75-75=0$

$\mathrm{A}_{3}, \mathrm{~A}_{8}=75-25=50$

$\mathrm{A}_{8}, \mathrm{~A}_{3}=25-75=-50$

$\mathrm{A}_{3}, \mathrm{~A}_{9}=75-75=0$

$\mathrm{A}_{9}, \mathrm{~A}_{3}=75-75=0$

$\mathrm{A}_{3}, \mathrm{~A}_{10}=75-75=0$

$\mathrm{A}_{10}, \mathrm{~A}_{3}=75-75=0$

$\mathrm{A}_{1}, \mathrm{~A}_{10}=25-75=-50$

$\mathrm{A}_{10}, \mathrm{~A}_{1}=75-25=50$

$\mathrm{A}_{4}, \mathrm{~A}_{5}=25-75=-50$

$\mathrm{A}_{5}, \mathrm{~A}_{6}=75-75=0$

$\mathrm{A}_{6}, \mathrm{~A}_{7}=75-75=0$

$\mathrm{A}_{5}, \mathrm{~A}_{4}=75-25=50$

$\mathrm{A}_{6}, \mathrm{~A}_{5}=75-75=0$

$\mathrm{A}_{7}, \mathrm{~A}_{6}=75-75=0$

$\mathrm{A}_{4}, \mathrm{~A}_{6}=25-75=-50$

$\mathrm{A}_{5}, \mathrm{~A}_{7}=75-75=0$

$\mathrm{A}_{7}, \mathrm{~A}_{5}=75-75=0$

$\mathrm{A}_{4}, \mathrm{~A}_{7}=25-75=-50$

$\mathrm{A}_{5}, \mathrm{~A}_{8}=75-25=50$

$\mathrm{A}_{6}, \mathrm{~A}_{8}=75-25=50$

$\mathrm{A}_{7}, \mathrm{~A}_{4}=75-25=50$

$\mathrm{A}_{4}, \mathrm{~A}_{8}=25-25=0$

$\mathrm{A}_{8}, \mathrm{~A}_{4}=25-25=0$

$\mathrm{A}_{8}, \mathrm{~A}_{5}=25-75=-50$

$\mathrm{A}_{8}, \mathrm{~A}_{6}=25-75=-50$

$\mathrm{A}_{6}, \mathrm{~A}_{9}=75-75=0$

$\mathrm{A}_{5}, \mathrm{~A}_{9}=75-75=0$

$\mathrm{A}_{9}, \mathrm{~A}_{5}=75-75=0$

$\mathrm{A}_{9}, \mathrm{~A}_{6}=75-75=0$

$\mathrm{A}_{4}, \mathrm{~A}_{9}=25-75=-50$

$\mathrm{A}_{5}, \mathrm{~A}_{10}=75-75=0$

$\mathrm{A}_{6}, \mathrm{~A}_{10}=75-75=0$

$\mathrm{A}_{9}, \mathrm{~A}_{4}=75-25=50$

$\mathrm{A}_{10}, \mathrm{~A}_{5}=75-75=0$ 
$\mathrm{A}_{4}, \mathrm{~A}_{10}=25-75=-50$

$\mathrm{A}_{10}, \mathrm{~A}_{4}=75-25=50$

$$
\begin{aligned}
& \mathrm{A}_{7}, \mathrm{~A}_{8}=75-25=50 \\
& \mathrm{~A}_{8}, \mathrm{~A}_{7}=25-75=-50 \\
& \mathrm{~A}_{7}, \mathrm{~A}_{9}=75-75=0 \\
& \mathrm{~A}_{9}, \mathrm{~A}_{7}=75-75=0 \\
& \mathrm{~A}_{7}, \mathrm{~A}_{10}=75-75=0 \\
& \mathrm{~A}_{10}, \mathrm{~A}_{7}=75-75=0
\end{aligned}
$$

b. Prestasi $\left(\mathrm{C}_{2}\right)$

$$
\begin{array}{ll}
\mathrm{A}_{1}, \mathrm{~A}_{2}=25-25=0 & \mathrm{~A}_{2}, \mathrm{~A}_{3}=25-50=-25 \\
\mathrm{~A}_{2}, \mathrm{~A}_{1}=25-25=0 & \mathrm{~A}_{3}, \mathrm{~A}_{2}=50-25=25 \\
\mathrm{~A}_{1}, \mathrm{~A}_{3}=25-50=-25 & \mathrm{~A}_{2}, \mathrm{~A}_{4}=25-50=-25 \\
\mathrm{~A}_{3}, \mathrm{~A}_{1}=50-25=25 & \mathrm{~A}_{4}, \mathrm{~A}_{2}=50-25=25 \\
\mathrm{~A}_{1}, \mathrm{~A}_{4}=25-50=-25 & \mathrm{~A}_{2}, \mathrm{~A}_{5}=25-100=-75 \\
\mathrm{~A}_{4}, \mathrm{~A}_{1}=50-25=25 & \mathrm{~A}_{5}, \mathrm{~A}_{2}=100-25=75 \\
\mathrm{~A}_{1}, \mathrm{~A}_{5}=25-100=-75 & \mathrm{~A}_{2}, \mathrm{~A}_{6}=25-25=0 \\
\mathrm{~A}_{5}, \mathrm{~A}_{1}=100-25=75 & \mathrm{~A}_{6}, \mathrm{~A}_{2}=25-25=0 \\
\mathrm{~A}_{1}, \mathrm{~A}_{6}=25-25=0 & \mathrm{~A}_{2}, \mathrm{~A}_{7}=25-50=-25 \\
\mathrm{~A}_{6}, \mathrm{~A}_{1}=25-25=0 & \mathrm{~A}_{7}, \mathrm{~A}_{2}=50-25=25 \\
\mathrm{~A}_{1}, \mathrm{~A}_{7}=25-50=-25 & \mathrm{~A}_{2}, \mathrm{~A}_{8}=25-50=-25 \\
\mathrm{~A}_{7}, \mathrm{~A}_{1}=50-25=25 & \mathrm{~A}_{8}, \mathrm{~A}_{2}=50-25=25 \\
\mathrm{~A}_{1}, \mathrm{~A}_{8}=25-50=-25 & \mathrm{~A}_{2}, \mathrm{~A}_{9}=25-100=-75 \\
\mathrm{~A}_{8}, \mathrm{~A}_{1}=50-25=25 & \mathrm{~A}_{9}, \mathrm{~A}_{2}=100-25=75 \\
\mathrm{~A}_{1}, \mathrm{~A}_{9}=25-100=-75 & \mathrm{~A}_{2}, \mathrm{~A}_{10}=25-25=0 \\
\mathrm{~A}_{9}, \mathrm{~A}_{1}=100-25=75 & \mathrm{~A}_{10}, \mathrm{~A}_{2}=25-25=0 \\
\mathrm{~A}_{1}, \mathrm{~A}_{1}=25-25=0 &
\end{array}
$$$$
\mathrm{A}_{1}, \mathrm{~A}_{10}=25-25=0
$$$$
\mathrm{A}_{10}, \mathrm{~A}_{1}=25-25=0
$$$$
\mathrm{A}_{4}, \mathrm{~A}_{5}=50-100=-50
$$$$
\mathrm{A}_{5}, \mathrm{~A}_{4}=100-50=50
$$$$
\mathrm{A}_{4}, \mathrm{~A}_{6}=50-25=25
$$$$
\mathrm{A}_{6}, \mathrm{~A}_{4}=25-50=-25
$$$$
\mathrm{A}_{4}, \mathrm{~A}_{7}=50-50=0
$$$$
\mathrm{A}_{7}, \mathrm{~A}_{4}=50-50=0
$$$$
\mathrm{A}_{4}, \mathrm{~A}_{8}=50-50=0
$$$$
\mathrm{A}_{8}, \mathrm{~A}_{4}=50-50=0
$$$$
\mathrm{A}_{4}, \mathrm{~A}_{9}=50-100=-50
$$$$
\mathrm{A}_{9}, \mathrm{~A}_{4}=100-50=50
$$$$
\mathrm{A}_{4}, \mathrm{~A}_{10}=50-25=25
$$$$
\mathrm{A}_{10}, \mathrm{~A}_{4}=25-50=-25
$$

$\mathrm{A}_{7}, \mathrm{~A}_{8}=50-50=0$

$\mathrm{A}_{8}, \mathrm{~A}_{7}=50-50=0$

$\mathrm{A}_{7}, \mathrm{~A}_{9}=50-100=-50$

$\mathrm{A}_{9}, \mathrm{~A}_{7}=100-50=50$

$\mathrm{A}_{7}, \mathrm{~A}_{10}=50-25=25$

$\mathrm{A}_{10}, \mathrm{~A}_{7}=25-50=-25$

c. Perilaku $\left(\mathrm{C}_{3}\right)$

$A_{1}, A_{2}=100-75=25$

$\mathrm{A}_{2}, \mathrm{~A}_{1}=75-100=-25$

$\mathrm{A}_{1}, \mathrm{~A}_{3}=100-75=25$

$\mathrm{A}_{3}, \mathrm{~A}_{1}=75-100=-25$

$\mathrm{A}_{1}, \mathrm{~A}_{4}=100-100=0$

$\mathrm{A}_{4}, \mathrm{~A}_{1}=100-100=0$

$\mathrm{A}_{1}, \mathrm{~A}_{5}=100-75=25$

$A_{5}, A_{1}=75-100=-25$

$\mathrm{A}_{1}, \mathrm{~A}_{6}=100-50=50$

$\mathrm{A}_{6}, \mathrm{~A}_{1}=50-100=-50$

$\mathrm{A}_{1}, \mathrm{~A}_{7}=100-75=25$
$\mathrm{A}_{8}, \mathrm{~A}_{9}=25-75=-50$

$\mathrm{A}_{9}, \mathrm{~A}_{8}=75-25=50$

$\mathrm{A}_{8}, \mathrm{~A}_{10}=25-75=-50$

$\mathrm{A}_{10}, \mathrm{~A}_{8}=75-25=50$

$\mathrm{A}_{5}, \mathrm{~A}_{6}=100-25=75$

$\mathrm{A}_{6}, \mathrm{~A}_{5}=25-100=-75$

$\mathrm{A}_{5}, \mathrm{~A}_{7}=100-50=50$

$\mathrm{A}_{7}, \mathrm{~A}_{5}=50-100=-50$

$\mathrm{A}_{5}, \mathrm{~A}_{8}=100-50=50$

$\mathrm{A}_{8}, \mathrm{~A}_{5}=50-100=-50$

$\mathrm{A}_{5}, \mathrm{~A}_{9}=100-100=0$

$\mathrm{A}_{9}, \mathrm{~A}_{5}=100-100=0$

$\mathrm{A}_{5}, \mathrm{~A}_{10}=100-25=75$

$\mathrm{A}_{10}, \mathrm{~A}_{5}=25-100=-75$

$\mathrm{A}_{8}, \mathrm{~A}_{9}=50-100=-50$

$\mathrm{A}_{9}, \mathrm{~A}_{8}=100-50=50$

$\mathrm{A}_{8}, \mathrm{~A}_{10}=50-25=25$

$\mathrm{A}_{10}, \mathrm{~A}_{8}=25-50=-25$

$\mathrm{A}_{2}, \mathrm{~A}_{3}=75-75=0$

$\mathrm{A}_{3}, \mathrm{~A}_{2}=75-75=0$

$\mathrm{A}_{2}, \mathrm{~A}_{4}=75-100=-25$

$\mathrm{A}_{4}, \mathrm{~A}_{2}=100-75=25$

$\mathrm{A}_{2}, \mathrm{~A}_{5}=75-75=0$

$\mathrm{A}_{5}, \mathrm{~A}_{2}=75-75=0$

$\mathrm{A}_{2}, \mathrm{~A}_{6}=75-50=25$

$\mathrm{A}_{2}, \mathrm{~A}_{7}=75-75=0$

$\mathrm{A}_{7}, \mathrm{~A}_{2}=75-75=0$

$\mathrm{A}_{2}, \mathrm{~A}_{8}=75-100=-25$
$\mathrm{A}_{6}, \mathrm{~A}_{2}=50-75=-25$
$\mathrm{A}_{9}, \mathrm{~A}_{10}=75-75=0$

$\mathrm{A}_{10}, \mathrm{~A}_{9}=75-75=0$

$\mathrm{A}_{10}, \mathrm{~A}_{10}=75-75=0$

$\mathrm{A}_{3}, \mathrm{~A}_{4}=50-50=0$

$\mathrm{A}_{4}, \mathrm{~A}_{3}=50-50=0$

$A_{3}, A_{5}=50-100=-50$

$\mathrm{A}_{5}, \mathrm{~A}_{3}=100-50=50$

$\mathrm{A}_{3}, \mathrm{~A}_{6}=50-25=25$

$\mathrm{A}_{6}, \mathrm{~A}_{3}=25-50=-25$

$\mathrm{A}_{3}, \mathrm{~A}_{7}=50-50=0$

$\mathrm{A}_{7}, \mathrm{~A}_{3}=50-50=0$

$\mathrm{A}_{3}, \mathrm{~A}_{8}=50-50=0$

$\mathrm{A}_{8}, \mathrm{~A}_{3}=50-50=0$

$\mathrm{A}_{3}, \mathrm{~A}_{9}=50-100=-50$

$\mathrm{A}_{9}, \mathrm{~A}_{3}=100-50=50$

$\mathrm{A}_{3}, \mathrm{~A}_{10}=50-25=25$

$\mathrm{A}_{10}, \mathrm{~A}_{3}=25-50=-25$

$\mathrm{A}_{6}, \mathrm{~A}_{7}=25-50=-25$

$\mathrm{A}_{7}, \mathrm{~A}_{6}=50-25=25$

$\mathrm{A}_{6}, \mathrm{~A}_{8}=25-50=-25$

$\mathrm{A}_{8}, \mathrm{~A}_{6}=50-25=25$

$\mathrm{A}_{6}, \mathrm{~A}_{9}=25-100=-75$

$\mathrm{A}_{9}, \mathrm{~A}_{6}=100-25=75$

$\mathrm{A}_{6}, \mathrm{~A}_{10}=25-25=0$

$\mathrm{A}_{10}, \mathrm{~A}_{6}=25-25=0$

$\mathrm{A}_{9}, \mathrm{~A}_{10}=100-25=75$

$\mathrm{A}_{10}, \mathrm{~A}_{9}=25-100=-75$

$\mathrm{A}_{10}, \mathrm{~A}_{10}=25-25=0$

$\mathrm{A}_{3}, \mathrm{~A}_{4}=75-100=-25$

$\mathrm{A}_{4}, \mathrm{~A}_{3}=100-75=25$

$\mathrm{A}_{3}, \mathrm{~A}_{5}=75-75=0$

$\mathrm{A}_{5}, \mathrm{~A}_{3}=75-75=0$

$\mathrm{A}_{3}, \mathrm{~A}_{6}=75-50=25$

$\mathrm{A}_{6}, \mathrm{~A}_{3}=50-75=-25$

$\mathrm{A}_{3}, \mathrm{~A}_{7}=75-75=0$

$\mathrm{A}_{7}, \mathrm{~A}_{3}=75-75=0$

$\mathrm{A}_{3}, \mathrm{~A}_{8}=75-100=-25$

$\mathrm{A}_{8}, \mathrm{~A}_{3}=100-75=25$

$\mathrm{A}_{3}, \mathrm{~A}_{9}=75-75=0$ 
$\mathrm{A}_{7}, \mathrm{~A}_{1}=75-100=-25$

$\mathrm{A}_{1}, \mathrm{~A}_{8}=100-100=0$

$\mathrm{A}_{8}, \mathrm{~A}_{1}=100-100=0$

$\mathrm{A}_{1}, \mathrm{~A}_{9}=100-75=25$

$A_{9}, A_{1}=75-100=-25$

$\mathrm{A}_{1}, \mathrm{~A}_{10}=100-50=50$

$\mathrm{A}_{10}, \mathrm{~A}_{1}=50-100=-50$

$\mathrm{A}_{4}, \mathrm{~A}_{5}=100-75=25$

$\mathrm{A}_{5}, \mathrm{~A}_{4}=75-100=-25$

$\mathrm{A}_{4}, \mathrm{~A}_{6}=100-50=50$

$\mathrm{A}_{6}, \mathrm{~A}_{4}=50-100=-50$

$\mathrm{A}_{4}, \mathrm{~A}_{7}=100-75=25$

$\mathrm{A}_{7}, \mathrm{~A}_{4}=75-100=-25$

$\mathrm{A}_{4}, \mathrm{~A}_{8}=100-100=0$

$\mathrm{A}_{8}, \mathrm{~A}_{4}=100-100=0$

$\mathrm{A}_{4}, \mathrm{~A}_{9}=100-75=25$

$\mathrm{A}_{9}, \mathrm{~A}_{4}=75-100=-25$

$\mathrm{A}_{4}, \mathrm{~A}_{10}=100-50=50$

$\mathrm{A}_{10}, \mathrm{~A}_{4}=50-100=-50$

$\mathrm{A}_{7}, \mathrm{~A}_{8}=75-100=-25$

$\mathrm{A}_{8}, \mathrm{~A}_{7}=100-75=25$

$\mathrm{A}_{7}, \mathrm{~A}_{9}=75-75=0$

$\mathrm{A}_{9}, \mathrm{~A}_{7}=75-75=0$

$\mathrm{A}_{7}, \mathrm{~A}_{10}=75-50=25$

$\mathrm{A}_{10}, \mathrm{~A}_{7}=50-75=-25$

d. Lama Bekerja $\left(\mathrm{C}_{4}\right)$

$\mathrm{A}_{1}, \mathrm{~A}_{2}=25-100=-75$

$\mathrm{A}_{2}, \mathrm{~A}_{1}=100-25=75$

$\mathrm{A}_{1}, \mathrm{~A}_{3}=25-50=-25$

$\mathrm{A}_{3}, \mathrm{~A}_{1}=50-25=25$

$\mathrm{A}_{1}, \mathrm{~A}_{4}=25-25=0$

$\mathrm{A}_{4}, \mathrm{~A}_{1}=25-25=0$

$\mathrm{A}_{1}, \mathrm{~A}_{5}=25-50=-25$

$\mathrm{A}_{5}, \mathrm{~A}_{1}=50-25=25$

$\mathrm{A}_{1}, \mathrm{~A}_{6}=25-75=-50$

$\mathrm{A}_{6}, \mathrm{~A}_{1}=75-25=50$

$\mathrm{A}_{1}, \mathrm{~A}_{7}=25-50=-25$

$\mathrm{A}_{7}, \mathrm{~A}_{1}=50-25=25$

$\mathrm{A}_{1}, \mathrm{~A}_{8}=25-25=0$

$\mathrm{A}_{8}, \mathrm{~A}_{1}=25-25=0$

$\mathrm{A}_{1}, \mathrm{~A}_{9}=25-50=-25$

$\mathrm{A}_{9}, \mathrm{~A}_{1}=50-25=25$

$\mathrm{A}_{1}, \mathrm{~A}_{10}=25-75=-50$

$\mathrm{A}_{10}, \mathrm{~A}_{1}=75-25=50$

$\mathrm{A}_{4}, \mathrm{~A}_{5}=25-50=-25$

$\mathrm{A}_{5}, \mathrm{~A}_{4}=50-25=25$

$\mathrm{A}_{4}, \mathrm{~A}_{6}=25-75=-50$

$\mathrm{A}_{6}, \mathrm{~A} 4=75-25=50$

$\mathrm{A}_{4}, \mathrm{~A}_{7}=25-50=-25$

$\mathrm{A}_{7}, \mathrm{~A}_{4}=50-25=25$

$\mathrm{A}_{4}, \mathrm{~A}_{8}=25-25=0$

$\mathrm{A}_{8}, \mathrm{~A}_{4}=25-25=0$

$\mathrm{A}_{4}, \mathrm{~A}_{9}=25-50=-25$

$\mathrm{A}_{9}, \mathrm{~A}_{4}=50-25=25$

$\mathrm{A}_{4}, \mathrm{~A}_{10}=25-75=-50$

$\mathrm{A}_{10}, \mathrm{~A}_{4}=75-25=50$

$\mathrm{A}_{7}, \mathrm{~A}_{8}=50-25=25$
$\mathrm{A}_{8}, \mathrm{~A}_{2}=100-75=25$

$\mathrm{A}_{2}, \mathrm{~A}_{9}=75-75=0$

$\mathrm{A}_{9}, \mathrm{~A}_{2}=75-75=0$

$\mathrm{A}_{2}, \mathrm{~A}_{10}=75-50=25$

$\mathrm{A}_{10}, \mathrm{~A}_{2}=50-75=-25$

$\mathrm{A}_{5}, \mathrm{~A}_{6}=75-50=25$

$\mathrm{A}_{6}, \mathrm{~A}_{5}=50-75=-25$

$\mathrm{A}_{5}, \mathrm{~A}_{7}=75-75=0$

$\mathrm{A}_{7}, \mathrm{~A}_{5}=75-75=0$

$\mathrm{A}_{5}, \mathrm{~A}_{8}=75-100=-25$

$\mathrm{A}_{8}, \mathrm{~A}_{5}=100-75=25$

$\mathrm{A}_{5}, \mathrm{~A}_{9}=75-75=0$

$\mathrm{A}_{9}, \mathrm{~A}_{5}=75-75=0$

$\mathrm{A}_{5}, \mathrm{~A}_{10}=75-50=25$

$\mathrm{A}_{10}, \mathrm{~A}_{5}=50-75=-25$

$\mathrm{A}_{8}, \mathrm{~A}_{9}=100-75=25$

$\mathrm{A}_{9}, \mathrm{~A}_{8}=75-100=-25$

$\mathrm{A}_{8}, \mathrm{~A}_{10}=100-50=50$

$\mathrm{A}_{10}, \mathrm{~A}_{8}=50-100=-50$

$\mathrm{A}_{2}, \mathrm{~A}_{3}=100-50=50$

$\mathrm{A}_{3}, \mathrm{~A}_{2}=50-100=-50$

$\mathrm{A}_{2}, \mathrm{~A}_{4}=100-25=75$

$\mathrm{A}_{4}, \mathrm{~A}_{2}=25-100=-75$

$\mathrm{A}_{2}, \mathrm{~A}_{5}=100-50=50$

$\mathrm{A}_{5}, \mathrm{~A}_{2}=50-100=-50$

$\mathrm{A}_{2}, \mathrm{~A}_{6}=100-75=25$

$\mathrm{A}_{6}, \mathrm{~A}_{2}=75-100=-25$

$\mathrm{A}_{2}, \mathrm{~A}_{7}=100-50=50$

$\mathrm{A}_{7}, \mathrm{~A}_{2}=50-100=-50$

$\mathrm{A}_{2}, \mathrm{~A}_{8}=100-25=75$

$\mathrm{A}_{8}, \mathrm{~A}_{2}=25-100=-75$

$\mathrm{A}_{2}, \mathrm{~A}_{9}=100-50=50$

$\mathrm{A}_{9}, \mathrm{~A}_{2}=50-100=-50$

$\mathrm{A}_{2}, \mathrm{~A}_{10}=100-75=25$

$\mathrm{A}_{10}, \mathrm{~A}_{2}=75-100=-25$

$\mathrm{A}_{5}, \mathrm{~A}_{6}=50-75=-25$

$\mathrm{A}_{6}, \mathrm{~A}_{5}=75-50=25$

$\mathrm{A}_{5}, \mathrm{~A}_{7}=50-50=0$

$\mathrm{A}_{7}, \mathrm{~A}_{5}=50-50=0$

$\mathrm{A}_{5}, \mathrm{~A}_{8}=50-25=25$

$\mathrm{A}_{8}, \mathrm{~A}_{5}=25-50=-25$

$\mathrm{A}_{5}, \mathrm{~A}_{9}=50-50=0$

$\mathrm{A}_{9}, \mathrm{~A}_{5}=50-50=0$

$\mathrm{A}_{5}, \mathrm{~A}_{10}=50-75=-25$

$\mathrm{A}_{10}, \mathrm{~A}_{5}=75-75=25$
$\mathrm{A}_{9}, \mathrm{~A}_{3}=75-75=0$

$\mathrm{A}_{3}, \mathrm{~A}_{10}=75-50=25$

$\mathrm{A}_{10}, \mathrm{~A}_{3}=50-75=-25$

$\mathrm{A}_{6}, \mathrm{~A}_{7}=50-75=-25$

$\mathrm{A}_{7}, \mathrm{~A}_{6}=75-50=25$

$\mathrm{A}_{6}, \mathrm{~A}_{8}=50-100=-50$

$\mathrm{A}_{8}, \mathrm{~A}_{6}=100-50=50$

$\mathrm{A}_{6}, \mathrm{~A}_{9}=50-75=-25$

$\mathrm{A}_{9}, \mathrm{~A}_{6}=75-50=25$

$\mathrm{A}_{6}, \mathrm{~A}_{10}=50-50=0$

$\mathrm{A}_{10}, \mathrm{~A}_{6}=50-50=0$

$\mathrm{A}_{9}, \mathrm{~A}_{10}=75-50=25$

$\mathrm{A}_{10}, \mathrm{~A}_{9}=50-75=-25$

$\mathrm{A}_{10}, \mathrm{~A}_{10}=50-50=0$

$\mathrm{A}_{3}, \mathrm{~A}_{4}=50-25=25$

$\mathrm{A}_{4}, \mathrm{~A}_{3}=25-50=-25$

$\mathrm{A}_{3}, \mathrm{~A}_{5}=50-50=0$

$\mathrm{A}_{5}, \mathrm{~A}_{3}=50-50=0$

$\mathrm{A}_{3}, \mathrm{~A}_{6}=50-75=-25$

$\mathrm{A}_{6}, \mathrm{~A}_{3}=75-50=25$

$\mathrm{A}_{3}, \mathrm{~A}_{7}=50-50=0$

$\mathrm{A}_{7}, \mathrm{~A}_{3}=50-50=0$

$\mathrm{A}_{3}, \mathrm{~A}_{8}=50-25=25$

$\mathrm{A}_{8}, \mathrm{~A}_{3}=25-50=-25$

$\mathrm{A}_{3}, \mathrm{~A}_{9}=50-50=0$

$\mathrm{A}_{9}, \mathrm{~A}_{3}=50-50=0$

$\mathrm{A}_{3}, \mathrm{~A}_{10}=50-75=-25$

$\mathrm{A}_{10}, \mathrm{~A}_{3}=75-75=25$

$\mathrm{A}_{6}, \mathrm{~A}_{7}=75-75=0$

$\mathrm{A}_{7}, \mathrm{~A}_{6}=75-75=0$

$\mathrm{A}_{6}, \mathrm{~A}_{8}=75-75=0$

$\mathrm{A}_{8}, \mathrm{~A}_{6}=75-75=0$

$\mathrm{A}_{6}, \mathrm{~A}_{9}=75-75=0$

$\mathrm{A}_{9}, \mathrm{~A}_{6}=75-75=0$

$\mathrm{A}_{6}, \mathrm{~A}_{10}=75-75=0$

$\mathrm{A}_{10}, \mathrm{~A}_{6}=75-75=0$

$A_{8}, A_{9}=25-50=-25$

$\mathrm{A}_{9}, \mathrm{~A}_{10}=50-75=-25$ 


$$
\begin{aligned}
& A_{8}, A_{7}=25-50=-25 \\
& A_{7}, A_{9}=50-50=0 \\
& A_{9}, A_{7}=50-50=0 \\
& A_{7}, A_{10}=50-75=-25 \\
& A_{10}, A_{7}=75-75=25
\end{aligned}
$$

e. Kerja Sama Tim $\left(\mathrm{C}_{5}\right)$

$$
\begin{aligned}
& A_{1}, A_{2}=100-75=25 \\
& A_{2}, A_{1}=75-100=-25 \\
& A_{1}, A_{3}=100-75=25 \\
& A_{3}, A_{1}=75-100=-25 \\
& A_{1}, A_{4}=100-75=25 \\
& A_{4}, A_{1}=75-100=-25 \\
& A_{1}, A_{5}=100-100=0 \\
& A_{5}, A_{1}=100-100=0 \\
& A_{1}, A_{6}=100-75=25 \\
& A_{6}, A_{1}=75-100=-25 \\
& A_{1}, A_{7}=100-76=25 \\
& A_{7}, A_{1}=75-100=-25 \\
& A_{1}, A_{8}=100-75=25 \\
& A_{8}, A_{1}=75-100=-25 \\
& A_{1}, A_{9}=100-100=0 \\
& A_{9}, A_{1}=100-100=0 \\
& A_{1}, A_{10}=100-75=25 \\
& A_{10}, A_{1}=75-100=-25 \\
& A_{4}, A_{5}=75-100=-25 \\
& A_{5}, A_{4}=100-75=25 \\
& A_{4}, A_{6}=75-75=0 \\
& A_{6}, A_{4}=75-50=0 \\
& A_{4}, A_{7}=75-75=0 \\
& A_{7}, A_{4}=75-75=0 \\
& A_{4}, A_{8}=75-75=0 \\
& A_{8}, A_{4}=75-75=0 \\
& A_{4}, A_{9}=75-100=-25 \\
& A_{9}, A_{4}=100-75=25 \\
& A_{4}, A_{10}=75-75=0 \\
& A_{10}, A_{4}=75-75=0 \\
& A_{7}, A_{8}=75-75=0 \\
& A_{8}, A_{7}=75-75=0 \\
& A_{7}, A_{9}=75-100=-25 \\
& A_{9}, A_{7}=100-75=25 \\
& A_{7}, A_{10}=75-75=0 \\
& A_{10}, A_{7}=75-75=0 \\
& A_{10}=0
\end{aligned}
$$

$\mathrm{A}_{10}, \mathrm{~A}_{9}=75-75=25$

$\mathrm{A}_{10}, \mathrm{~A}_{10}=75-75=0$
$A_{9}, A_{8}=50-25=25$
$A_{8}, A_{10}=25-75=-50$
$A_{10}, A_{8}=75-25=50$
$\mathrm{A}_{2}, \mathrm{~A}_{3}=75-75=0$
$\mathrm{A}_{3}, \mathrm{~A}_{2}=75-75=0$
$\mathrm{A}_{2}, \mathrm{~A}_{4}=75-75=0$
$\mathrm{A}_{4}, \mathrm{~A}_{2}=75-75=0$
$\mathrm{A}_{2}, \mathrm{~A}_{5}=75-100=-25$
$\mathrm{A}_{5}, \mathrm{~A}_{2}=100-75=25$
$\mathrm{A}_{2}, \mathrm{~A}_{6}=75-75=0$
$\mathrm{A}_{6}, \mathrm{~A}_{2}=75-50=0$
$\mathrm{A}_{2}, \mathrm{~A}_{7}=75-75=0$
$\mathrm{A}_{7}, \mathrm{~A}_{2}=75-75=0$
$\mathrm{A}_{2}, \mathrm{~A}_{8}=75-75=0$
$\mathrm{A}_{8}, \mathrm{~A}_{2}=75-75=0$
$\mathrm{A}_{2}, \mathrm{~A} 9=75-100=-25$
$\mathrm{A}_{9}, \mathrm{~A}_{2}=100-75=25$

\begin{abstract}
$\mathrm{A}_{3}, \mathrm{~A}_{4}=75-75=0$
$\mathrm{A}_{4}, \mathrm{~A}_{3}=75-75=0$

$\mathrm{A}_{3}, \mathrm{~A}_{5}=75-100=-25$

$\mathrm{A}_{5}, \mathrm{~A}_{3}=100-75=25$

$\mathrm{A}_{3}, \mathrm{~A}_{6}=75-75=0$

$\mathrm{A}_{6}, \mathrm{~A}_{3}=75-50=0$

$\mathrm{A}_{3}, \mathrm{~A}_{7}=75-75=0$

$\mathrm{A}_{7}, \mathrm{~A}_{3}=75-75=0$

$\mathrm{A}_{3}, \mathrm{~A}_{8}=75-75=0$

$\mathrm{A}_{8}, \mathrm{~A}_{3}=75-75=0$

$\mathrm{A}_{3}, \mathrm{~A}_{9}=75-100=-25$

$\mathrm{A}_{9}, \mathrm{~A}_{3}=100-75=25$

$\mathrm{A}_{3}, \mathrm{~A}_{10}=75-75=0$

$\mathrm{A}_{10}, \mathrm{~A}_{3}=75-75=0$
\end{abstract}

$\mathrm{A}_{2}, \mathrm{~A}_{10}=75-75=0$

$\mathrm{A}_{10}, \mathrm{~A}_{2}=75-75=0$

$\begin{array}{ll}\mathrm{A}_{5}, \mathrm{~A}_{6}=100-75=25 & \mathrm{~A}_{6}, \mathrm{~A}_{7}=75-75=0 \\ \mathrm{~A}_{6}, \mathrm{~A}_{5}=75-100=-25 & \mathrm{~A}_{7}, \mathrm{~A}_{6}=75-75=0 \\ \mathrm{~A}_{5}, \mathrm{~A}_{7}=100-76=25 & \mathrm{~A}_{6}, \mathrm{~A}_{8}=75-75=0 \\ \mathrm{~A}_{7}, \mathrm{~A}_{5}=75-100=-25 & \mathrm{~A}_{8}, \mathrm{~A}_{6}=75-75=0 \\ \mathrm{~A}_{5}, \mathrm{~A}_{8}=100-75=25 & \mathrm{~A}_{6}, \mathrm{~A}_{9}=75-100=-25 \\ \mathrm{~A}_{8}, \mathrm{~A}_{5}=75-100=-25 & \mathrm{~A}_{9}, \mathrm{~A}_{6}=100-75=25 \\ \mathrm{~A}_{5}, \mathrm{~A}_{9}=100-100=0 & \mathrm{~A}_{6}, \mathrm{~A}_{10}=75-75=0 \\ \mathrm{~A}_{9}, \mathrm{~A}_{5}=100-100=0 & \mathrm{~A}_{10}, \mathrm{~A}_{6}=75-75=0\end{array}$

$\mathrm{A}_{5}, \mathrm{~A}_{10}=100-75=25$

$\mathrm{A}_{10}, \mathrm{~A}_{5}=75-100=-25$

$$
\begin{aligned}
& A_{8}, A_{9}=75-100=-25 \\
& A_{9}, A_{8}=100-75=25 \\
& A_{8}, A_{10}=75-75=0 \\
& A_{10}, A_{8}=75-75=0
\end{aligned}
$$




\begin{tabular}{|c|c|c|c|c|c|c|c|c|c|c|c|c|c|}
\hline \multirow{2}{*}{\multicolumn{2}{|c|}{ Alternatif }} & \multicolumn{5}{|c|}{ Preferensi } & \multirow{2}{*}{\multicolumn{2}{|c|}{ Alternatif }} & \multicolumn{5}{|c|}{ Preferensi } \\
\hline & & $\mathrm{C}_{1}$ & $\mathrm{C}_{2}$ & $\mathrm{C}_{3}$ & $\mathrm{C}_{4}$ & $\mathrm{C}_{5}$ & & & $\mathrm{C}_{1}$ & $\mathrm{C}_{2}$ & $\mathrm{C}_{3}$ & $\mathrm{C}_{4}$ & $\mathrm{C}_{5}$ \\
\hline $\mathrm{A}_{2}$ & $\mathrm{~A}_{1}$ & 1 & 0 & 0 & 1 & 0 & $\mathrm{~A}_{7}$ & $\mathrm{~A}_{1}$ & 1 & 1 & 0 & 1 & 0 \\
\hline $\mathrm{A}_{2}$ & $\mathrm{~A}_{2}$ & 0 & 0 & 0 & 0 & 0 & $\mathrm{~A}_{7}$ & $\mathrm{~A}_{2}$ & 1 & 1 & 0 & 0 & 0 \\
\hline $\mathrm{A}_{2}$ & $\mathrm{~A}_{3}$ & 0 & 0 & 0 & 1 & 0 & $\mathrm{~A}_{7}$ & $\mathrm{~A}_{3}$ & 0 & 0 & 0 & 0 & 0 \\
\hline $\mathrm{A}_{2}$ & $\mathrm{~A}_{4}$ & 1 & 0 & 0 & 1 & 0 & $\mathrm{~A}_{7}$ & $\mathrm{~A}_{4}$ & 1 & 0 & 0 & 1 & 0 \\
\hline $\mathrm{A}_{2}$ & $\mathrm{~A}_{5}$ & 0 & 0 & 0 & 1 & 0 & $\mathrm{~A}_{7}$ & $\mathrm{~A}_{5}$ & 0 & 0 & 0 & 0 & 0 \\
\hline $\mathrm{A}_{2}$ & $\mathrm{~A}_{6}$ & 0 & 0 & 1 & 1 & 0 & $\mathrm{~A}_{7}$ & $\mathrm{~A}_{6}$ & 0 & 1 & 1 & 0 & 0 \\
\hline $\mathrm{A}_{2}$ & $\mathrm{~A}_{7}$ & 0 & 0 & 0 & 1 & 0 & $\mathrm{~A}_{7}$ & $\mathrm{~A}_{7}$ & 0 & 0 & 0 & 0 & 0 \\
\hline $\mathrm{A}_{2}$ & $\mathrm{~A}_{8}$ & 1 & 0 & 0 & 1 & 0 & $\mathrm{~A}_{7}$ & $\mathrm{~A}_{8}$ & 1 & 0 & 0 & 1 & 0 \\
\hline $\mathrm{A}_{2}$ & $\mathrm{~A}_{9}$ & 0 & 0 & 0 & 1 & 0 & $\mathrm{~A}_{7}$ & $\mathrm{~A}_{9}$ & 0 & 0 & 0 & 0 & 0 \\
\hline $\mathrm{A}_{2}$ & $\mathrm{~A}_{10}$ & 0 & 0 & 1 & 1 & 0 & $\mathrm{~A}_{7}$ & $\mathrm{~A}_{10}$ & 0 & 1 & 1 & 0 & 0 \\
\hline $\mathrm{A}_{3}$ & $\mathrm{~A}_{1}$ & 1 & 1 & 0 & 1 & 0 & $\mathrm{~A}_{8}$ & $\mathrm{~A}_{1}$ & 0 & 1 & 0 & 0 & 0 \\
\hline $\mathrm{A}_{3}$ & $\mathrm{~A}_{2}$ & 1 & 1 & 0 & 0 & 0 & $\mathrm{~A}_{8}$ & $\mathrm{~A}_{2}$ & 0 & 1 & 1 & 0 & 0 \\
\hline $\mathrm{A}_{3}$ & $\mathrm{~A}_{3}$ & 0 & 0 & 0 & 0 & 0 & $\mathrm{~A}_{8}$ & $\mathrm{~A}_{3}$ & 0 & 0 & 1 & 0 & 0 \\
\hline $\mathrm{A}_{3}$ & $\mathrm{~A}_{4}$ & 1 & 0 & 0 & 1 & 0 & $\mathrm{~A}_{8}$ & $\mathrm{~A}_{4}$ & 0 & 0 & 0 & 0 & 0 \\
\hline $\mathrm{A}_{3}$ & $\mathrm{~A}_{5}$ & 0 & 0 & 0 & 0 & 0 & $\mathrm{~A}_{8}$ & $\mathrm{~A}_{5}$ & 0 & 0 & 1 & 0 & 0 \\
\hline $\mathrm{A}_{3}$ & $\mathrm{~A}_{6}$ & 0 & 1 & 1 & 0 & 0 & $\mathrm{~A}_{8}$ & $\mathrm{~A}_{6}$ & 0 & 1 & 1 & 0 & 0 \\
\hline $\mathrm{A}_{3}$ & $\mathrm{~A}_{7}$ & 0 & 0 & 0 & 0 & 0 & $\mathrm{~A}_{8}$ & $\mathrm{~A}_{7}$ & 0 & 0 & 1 & 0 & 0 \\
\hline $\mathrm{A}_{3}$ & $\mathrm{~A}_{8}$ & 1 & 0 & 0 & 1 & 0 & $\mathrm{~A}_{8}$ & $\mathrm{~A}_{8}$ & 0 & 0 & 0 & 0 & 0 \\
\hline $\mathrm{A}_{3}$ & $\mathrm{~A}_{9}$ & 0 & 0 & 0 & 0 & 0 & $\mathrm{~A}_{8}$ & $\mathrm{~A}_{9}$ & 0 & 0 & 1 & 0 & 0 \\
\hline $\mathrm{A}_{3}$ & $\mathrm{~A}_{10}$ & 0 & 1 & 1 & 0 & 0 & $\mathrm{~A}_{8}$ & $\mathrm{~A}_{10}$ & 0 & 1 & 1 & 0 & 0 \\
\hline $\mathrm{A}_{4}$ & $\mathrm{~A}_{1}$ & 0 & 1 & 0 & 0 & 0 & $\mathrm{~A}_{9}$ & $\mathrm{~A}_{1}$ & 1 & 1 & 0 & 1 & 0 \\
\hline $\mathrm{A}_{4}$ & $\mathrm{~A}_{2}$ & 0 & 1 & 1 & 0 & 0 & $\mathrm{~A}_{9}$ & $\mathrm{~A}_{2}$ & 1 & 1 & 0 & 0 & 1 \\
\hline $\mathrm{A}_{4}$ & $\mathrm{~A}_{3}$ & 0 & 0 & 1 & 0 & 0 & $\mathrm{~A}_{9}$ & $\mathrm{~A}_{3}$ & 0 & 1 & 0 & 0 & 1 \\
\hline $\mathrm{A}_{4}$ & $\mathrm{~A}_{4}$ & 0 & 0 & 0 & 0 & 0 & $\mathrm{~A}_{9}$ & $\mathrm{~A}_{4}$ & 1 & 1 & 0 & 1 & 1 \\
\hline $\mathrm{A}_{4}$ & $\mathrm{~A}_{5}$ & 0 & 0 & 1 & 0 & 0 & $\mathrm{~A}_{9}$ & $\mathrm{~A}_{5}$ & 0 & 0 & 0 & 0 & 0 \\
\hline \multirow{2}{*}{\multicolumn{2}{|c|}{ Alternatif }} & \multicolumn{5}{|c|}{ Preferensi } & \multirow{2}{*}{\multicolumn{2}{|c|}{ Alternatif }} & \multicolumn{5}{|c|}{ Preferensi } \\
\hline & & $\mathrm{C}_{1}$ & $\mathrm{C}_{2}$ & $\mathrm{C}_{3}$ & $\mathrm{C}_{4}$ & $\mathrm{C}_{5}$ & & & $\mathrm{C}_{1}$ & $\mathrm{C}_{2}$ & $\mathrm{C}_{3}$ & $\mathrm{C}_{4}$ & $\mathrm{C}_{5}$ \\
\hline $\mathrm{A}_{4}$ & $\mathrm{~A}_{6}$ & 0 & 1 & 1 & 0 & 0 & $\mathrm{~A}_{9}$ & $\mathrm{~A}_{6}$ & 0 & 1 & 1 & 0 & 1 \\
\hline $\mathrm{A}_{4}$ & $\mathrm{~A}_{7}$ & 0 & 0 & 1 & 0 & 0 & $\mathrm{~A}_{9}$ & $\mathrm{~A}_{7}$ & 0 & 1 & 0 & 0 & 1 \\
\hline $\mathrm{A}_{4}$ & $\mathrm{~A}_{8}$ & 0 & 0 & 0 & 0 & 0 & $\mathrm{~A}_{9}$ & $\mathrm{~A}_{8}$ & 1 & 1 & 0 & 1 & 1 \\
\hline $\mathrm{A}_{4}$ & $\mathrm{~A}_{9}$ & 0 & 0 & 1 & 0 & 0 & $\mathrm{~A}_{9}$ & $\mathrm{~A}_{9}$ & 0 & 0 & 0 & 0 & 0 \\
\hline $\mathrm{A}_{4}$ & $\mathrm{~A}_{10}$ & 0 & 1 & 1 & 0 & 0 & $\mathrm{~A}_{9}$ & $\mathrm{~A}_{10}$ & 0 & 1 & 1 & 0 & 1 \\
\hline $\mathrm{A}_{5}$ & $\mathrm{~A}_{1}$ & 1 & 1 & 0 & 1 & 0 & $\mathrm{~A}_{10}$ & $\mathrm{~A}_{1}$ & 1 & 0 & 0 & 1 & 0 \\
\hline $\mathrm{A}_{5}$ & $\mathrm{~A}_{2}$ & 1 & 1 & 0 & 0 & 1 & $\mathrm{~A}_{10}$ & $\mathrm{~A}_{2}$ & 1 & 0 & 0 & 0 & 0 \\
\hline $\mathrm{A}_{5}$ & $\mathrm{~A}_{3}$ & 0 & 1 & 0 & 0 & 1 & $\mathrm{~A}_{10}$ & $\mathrm{~A}_{3}$ & 0 & 0 & 0 & 1 & 0 \\
\hline $\mathrm{A}_{5}$ & $\mathrm{~A}_{4}$ & 1 & 1 & 0 & 1 & 1 & $\mathrm{~A}_{10}$ & $\mathrm{~A}_{4}$ & 1 & 0 & 0 & 1 & 0 \\
\hline $\mathrm{A}_{5}$ & $\mathrm{~A}_{5}$ & 0 & 0 & 0 & 0 & 0 & $\mathrm{~A}_{10}$ & $\mathrm{~A}_{5}$ & 0 & 0 & 0 & 1 & 0 \\
\hline $\mathrm{A}_{5}$ & $\mathrm{~A}_{6}$ & 0 & 1 & 1 & 0 & 1 & $\mathrm{~A}_{10}$ & $\mathrm{~A}_{6}$ & 0 & 0 & 0 & 0 & 0 \\
\hline $\mathrm{A}_{5}$ & $\mathrm{~A}_{7}$ & 0 & 1 & 0 & 0 & 1 & $\mathrm{~A}_{10}$ & $\mathrm{~A}_{7}$ & 0 & 0 & 0 & 1 & 0 \\
\hline $\mathrm{A}_{5}$ & $\mathrm{~A}_{8}$ & 1 & 1 & 0 & 1 & 1 & $\mathrm{~A}_{10}$ & $\mathrm{~A}_{8}$ & 1 & 0 & 0 & 1 & 0 \\
\hline $\mathrm{A}_{5}$ & $\mathrm{~A}_{9}$ & 0 & 0 & 0 & 0 & 0 & $\mathrm{~A}_{10}$ & $\mathrm{~A}_{9}$ & 0 & 0 & 0 & 1 & 0 \\
\hline $\mathrm{A}_{5}$ & $\mathrm{~A}_{10}$ & 0 & 1 & 1 & 0 & 1 & $\mathrm{~A}_{10}$ & $\mathrm{~A}_{10}$ & 0 & 0 & 0 & 0 & 0 \\
\hline
\end{tabular}

\subsubsection{Mencari Nilai Indeks Preferensi Multikriteria}

Setelah mencari nilai prefrensi untuk setiap alternatif, selanjutnya menghitung indeks prefrensi dengan menjumlahkan nilai prefrensi dibagi dengan jumlah kriteria.

Tabel 11. Indeks Prefrensi Multikriteria

\begin{tabular}{ccccccccccc}
\hline & $\mathrm{A}_{1}$ & $\mathrm{~A}_{2}$ & $\mathrm{~A}_{3}$ & $\mathrm{~A}_{4}$ & $\mathrm{~A}_{5}$ & $\mathrm{~A}_{6}$ & $\mathrm{~A}_{7}$ & $\mathrm{~A}_{8}$ & $\mathrm{~A}_{9}$ & $\mathrm{~A}_{10}$ \\
\hline $\mathrm{A}_{1}$ & 0 & 0,4 & 0,4 & 0,2 & 0,2 & 0,4 & 0,4 & 0,2 & 0,2 & 0,4 \\
$\mathrm{~A}_{2}$ & 0,4 & 0 & 0,2 & 0,4 & 0,2 & 0,4 & 0,2 & 0,4 & 0,2 & 0,4 \\
$\mathrm{~A}_{3}$ & 0,6 & 0,4 & 0 & 0,4 & 0 & 0,4 & 0 & 0,4 & 0 & 0,4 \\
$\mathrm{~A}_{4}$ & 0,2 & 0,4 & 0,2 & 0 & 0,2 & 0,4 & 0,2 & 0 & 0,2 & 0,4 \\
$\mathrm{~A}_{5}$ & 0,6 & 0,6 & 0,4 & 0,8 & 0 & 0,6 & 0,4 & 0,8 & 0 & 0,6 \\
$\mathrm{~A}_{6}$ & 0,4 & 0,2 & 0,3 & 0,4 & 0,2 & 0 & 0 & 0,2 & 0 & 0 \\
$\mathrm{~A}_{7}$ & 0,6 & 0,4 & 0 & 0,4 & 0 & 0,4 & 0 & 0,4 & 0 & 0,4 \\
$\mathrm{~A}_{8}$ & 0,2 & 0,4 & 0,2 & 0 & 0,2 & 0,4 & 0,2 & 0 & 0,2 & 0,4 \\
$\mathrm{~A}_{9}$ & 0,6 & 0,6 & 0,4 & 0,8 & 0 & 0,6 & 0,4 & 0,8 & 0 & 0,6 \\
$\mathrm{~A}_{10}$ & 0,4 & 0,2 & 0,2 & 0,4 & 0,2 & 0 & 0,2 & 0,4 & 0,2 & 0 \\
\hline
\end{tabular}




\subsubsection{Menghitung Leaving Flow dan Entering Flow}

Setelah nilai indeks preferensi multikriteria di peroleh dilanjutkan dengan pemeringkatan dengan Promethee I yaitu pemeringkatan berdasarkan leaving flow menggunakan persamaan (7) dan entering flow menggunakan persamaan (8).

Tabel 12. Pemeringkatan Leaving Flow

\begin{tabular}{ccccccccccccc}
\hline & $\mathrm{A}_{1}$ & $\mathrm{~A}_{2}$ & $\mathrm{~A}_{3}$ & $\mathrm{~A}_{4}$ & $\mathrm{~A}_{5}$ & $\mathrm{~A}_{6}$ & $\mathrm{~A}_{7}$ & $\mathrm{~A}_{8}$ & $\mathrm{~A}_{9}$ & $\mathrm{~A}_{10}$ & $\sum$ & $\mathrm{LF}$ \\
\hline $\mathrm{A}_{1}$ & 0 & 0,4 & 0,4 & 0,2 & 0,2 & 0,4 & 0,4 & 0,2 & 0,2 & 0,4 & 2,8 & 0,311 \\
$\mathrm{~A}_{2}$ & 0,4 & 0 & 0,2 & 0,4 & 0,2 & 0,4 & 0,2 & 0,4 & 0,2 & 0,4 & 2,8 & 0,311 \\
$\mathrm{~A}_{3}$ & 0,6 & 0,4 & 0 & 0,4 & 0 & 0,4 & 0 & 0,4 & 0 & 0,4 & 2,6 & 0,289 \\
$\mathrm{~A}_{4}$ & 0,2 & 0,4 & 0,2 & 0 & 0,2 & 0,4 & 0,2 & 0 & 0,2 & 0,4 & 2,2 & 0,244 \\
$\mathrm{~A}_{5}$ & 0,6 & 0,6 & 0,4 & 0,8 & 0 & 0,6 & 0,4 & 0,8 & 0 & 0,6 & 4,8 & 0,533 \\
$\mathrm{~A}_{6}$ & 0,4 & 0,2 & 0,3 & 0,4 & 0,2 & 0 & 0 & 0,2 & 0 & 0 & 1,7 & 0,189 \\
$\mathrm{~A}_{7}$ & 0,6 & 0,4 & 0 & 0,4 & 0 & 0,4 & 0 & 0,4 & 0 & 0,4 & 2,6 & 0,289 \\
$\mathrm{~A}_{8}$ & 0,2 & 0,4 & 0,2 & 0 & 0,2 & 0,4 & 0,2 & 0 & 0,2 & 0,4 & 2,2 & 0,244 \\
$\mathrm{~A}_{9}$ & 0,6 & 0,6 & 0,4 & 0,8 & 0 & 0,6 & 0,4 & 0,8 & 0 & 0,6 & 4,8 & 0,533 \\
$\mathrm{~A}_{10}$ & 0,4 & 0,2 & 0,2 & 0,4 & 0,2 & 0 & 0,2 & 0,4 & 0,2 & 0 & 2,2 & 0,244 \\
\hline
\end{tabular}

Tabel 13. Pemeringkatan Entering Flow

\begin{tabular}{ccccccccccc}
\hline & $\mathrm{A}_{1}$ & $\mathrm{~A}_{2}$ & $\mathrm{~A}_{3}$ & $\mathrm{~A}_{4}$ & $\mathrm{~A}_{5}$ & $\mathrm{~A}_{6}$ & $\mathrm{~A}_{7}$ & $\mathrm{~A}_{8}$ & $\mathrm{~A}_{9}$ & $\mathrm{~A}_{10}$ \\
\hline $\mathrm{A}_{1}$ & 0 & 0,4 & 0,4 & 0,2 & 0,2 & 0,4 & 0,4 & 0,2 & 0,2 & 0,4 \\
$\mathrm{~A}_{2}$ & 0,4 & 0 & 0,2 & 0,4 & 0,2 & 0,4 & 0,2 & 0,4 & 0,2 & 0,4 \\
$\mathrm{~A}_{3}$ & 0,6 & 0,4 & 0 & 0,4 & 0 & 0,4 & 0 & 0,4 & 0 & 0,4 \\
$\mathrm{~A}_{4}$ & 0,2 & 0,4 & 0,2 & 0 & 0,2 & 0,4 & 0,2 & 0 & 0,2 & 0,4 \\
$\mathrm{~A}_{5}$ & 0,6 & 0,6 & 0,4 & 0,8 & 0 & 0,6 & 0,4 & 0,8 & 0 & 0,6 \\
$\mathrm{~A}_{6}$ & 0,4 & 0,2 & 0,3 & 0,4 & 0,2 & 0 & 0 & 0,2 & 0 & 0 \\
$\mathrm{~A}_{7}$ & 0,6 & 0,4 & 0 & 0,4 & 0 & 0,4 & 0 & 0,4 & 0 & 0,4 \\
$\mathrm{~A}_{8}$ & 0,2 & 0,4 & 0,2 & 0 & 0,2 & 0,4 & 0,2 & 0 & 0,2 & 0,4 \\
$\mathrm{~A}_{9}$ & 0,6 & 0,6 & 0,4 & 0,8 & 0 & 0,6 & 0,4 & 0,8 & 0 & 0,6 \\
$\mathrm{~A}_{10}$ & 0,4 & 0,2 & 0,2 & 0,4 & 0,2 & 0 & 0,2 & 0,4 & 0,2 & 0 \\
$\sum$ & 4 & 3,6 & 2,3 & 3,8 & 1,2 & 3,6 & 2 & 3,6 & 1 & 3,6 \\
$\mathrm{EF}$ & 0,444 & 0,400 & 0,256 & 0,422 & 0,133 & 0,400 & 0,222 & 0,400 & 0,111 & 0,400 \\
\hline
\end{tabular}

\subsubsection{Menghitung Net Flow}

Selanjutnya untuk keputusan akhir digunakan pemeringkatan dengan Promethee II berdasarkan nilai net flow. Nilai net flow diperoleh dengan cara mengurangkan nilai pemeringkatan leaving flow dan entering flow menggunakan persamaan (9).

Tabel 12. Pemeringkatan Net Flow

\begin{tabular}{cccc}
\hline Alternatif & Leaving Flow & Entering Flow & Net Flow \\
\hline A1 & 0,311 & 0,444 & $-0,133$ \\
A2 & 0,311 & 0,400 & $-0,089$ \\
A3 & 0,289 & 0,256 & 0,033 \\
A4 & 0,244 & 0,422 & $-0,178$ \\
A5 & 0,533 & 0,133 & 0,400 \\
A6 & 0,189 & 0,400 & $-0,211$ \\
A7 & 0,289 & 0,222 & 0,067 \\
A8 & 0,244 & 0,400 & $-0,156$ \\
A9 & 0,533 & 0,111 & 0,422 \\
A10 & 0,244 & 0,400 & $-0,156$ \\
\hline
\end{tabular}

\subsubsection{Menentukan Rangking Setiap Alternatif}

Setelang menghitung nilai leaving flow, entering flow, dan net flow maka masuk ke dalam tahap perangkingan.

Tabel 13. Hasil Pemeringkatan Berdasarkan Net Flow

\begin{tabular}{ccc}
\hline & Net Flow & Rank \\
\hline A1 & $-0,133$ & 6 \\
A2 & $-0,089$ & 5 \\
A3 & 0,033 & 4 \\
A4 & $-0,178$ & 9 \\
\hline
\end{tabular}




\begin{tabular}{ccc}
\hline & Net Flow & Rank \\
\hline A5 & 0,400 & 2 \\
A6 & $-0,211$ & 10 \\
A7 & 0,067 & 3 \\
A8 & $-0,156$ & 7 \\
A9 & 0,422 & 1 \\
A10 & $-0,156$ & 8 \\
\hline
\end{tabular}

Berdasarkan hasil dari pembahasan diatas, dapat dilihat bahwa sistem pendukung keputusan dengan algoritma Promethee dan dapat menangani masalah dalam penentuan Pegawai THLyang berhak mendapatkan insentif pada Kantor Walikota Pematangsintar .

Berdasarkan hasil penelitian didapatkan alternatif dengan nilai net flow tertinggi yaitu A9 atas nama Triono dengan nilai 0,422 dan alternatif dengan nilai net flow terendah yaitu A6 atas nama Herman. Dengan ranking dari nilai tertinnggi ke nilai terendah adalah sebagai berikut : Triono (A9), Niko (A5), Rani (A7), Safii, (A3), Anto (A2), Suparman (A1), Safira (A7), Soraya (A10), Rasid (A4), dan Herman (A6). Dalam hal ini Pegawai THL yang mendapatkan insentif dapat disesuaikan dengan urutan perangkingan.

\section{KESIMPULAN}

Berdasarkan hasil analisis dan pembahasan pada bab sebelumnya, penulis mengambil beberapa keseimpulan bahwa sistem pendukung keputusan dengan metode Promethee ini dapat membantu Pimpinan dalam menetukan Pegawai THL yang berhak mendapatkan insentif dengan memberikan rekomendasi dari beberapa alternatif yang diberikan. Keputusan yang diberikan oleh metode Promethee adalah hasil perbandingan setiap alternatif berdasarkan kriteria penilaian dengan preferensi dan bobot kriteria yang berbeda - beda sehingga menghasilkan keputusan yang lebih objektif. Penambahan kriteria penilaian untuk setiap alternatif dapat mempengaruhi penilaian dan hasil perhitungan metode promethee.

\section{REFERENCES}

[1] R. Stevanus, R. I. Handayani, and D. A. Kristiyanti, "Sistem Pendukung Keputusan Pemberian Bonus Karyawan Menggunakan Metode Ahp Pada Rumah Sakit Buah Hati Ciputat,” J. PILAR Nusa Mandiri, vol. 2, no. 2, pp. 1-8, 2018.

[2] D. Prabowo, B. W. Sari, and K. Kunci, "Fuzzy Tsukamoto Dan Mamdani Untuk Penentuan Bonus Gaji Pegawai PT. Indonesia IT," INFOS J., vol. 2, no. 1, pp. 25-31, 2019.

[3] A. Handoko, L. L. Van Fc, and Y. Yunefri, "Sistem Pendukung Keputusan Perpanjangan Kontrak Tenaga Harian Lepas (THL) Di Dinas Pendidikan Kota Pekanbaru Menggunakan Metode Analytical Hierarchy Prosess Dan Profile Matching," in Seminar Nasional Teknologi Informasi \& Ilmu Komputer (SEMASTER), 2020, vol. 1, no. 1, pp. 191-198.

[4] S. R. Handayani and B. Noranita, "Penerapan Metode Promethee Dalam Menentukan Prioritas Penerima Kredit," JMASIF (Jurnal Masy. Inform., vol. 9, pp. 1-9, 2018.

[5] Lili Tanti, "Penentuan Prioritas Penerima Permohonan Pengajuan Kredit Barang dengan Penerapan Metode Promethee," Semin. Nas. Teknol. Inf. dan Multimed., vol. 1, no. Sistem Pendukung Keputusan, p. 1.3-1-1.3-6, 2016.

[6] T. Novika, A. Widiastari, V. Miralda, and A. P. Windarto, "SPK: ANALISA REKOMENDASI BANK KONVENSIONAL DENGAN PROMETHEE SEBAGAI SOLUSI CERDAS UNTUK MENABUNG,” vol. 3, no. 1, pp. 38-45, 2018.

[7] A. F. Telaumbanua, M. Syahrizal, and M. Murdani, "Sistem Pendukung Keputusan Dalam Menentukan Jenis Pohon Pelindung Yang Akan di Tanam Dipinggir Jalan Menggunakan Metode Promethee II," JSON (Jurnal Sist. Komput. dan Inform., vol. 1, no. 3, p. 226, 2020.

[8] M. I. Sukmana, "Penerapan Metode PROMETHEE II Dalam Karyawan Terbaik Pada Pusat Penelitian Kelapa Sawit Area Medan,” JSON (Jurnal Sist. Komput. dan Inform., vol. 2, no. Promethee Ii, pp. 141-154, 2021.

[9] T. Imandasari, A. Wanto, and A. P. Windarto, "Analisis Pengambilan Keputusan Dalam Menentukan Mahasiswa PKL Menggunakan Metode PROMETHEE,” J. Ris. Komput., vol. 5, no. 3, pp. 234-239, 2018.

[10] I. P. Pertiwi, F. Fedinandus, and A. D. Limantara, "Sistem Pendukung Keputusan Penerima Program Keluarga Harapan (PKH) Menggunakan Metode Simple Additive Weighting," CAHAYAtech, vol. 8, no. 2, p. 182, 2019.

[11] T. Limbong et al., Sistem Pendukung Keputusan: Metode \& Implementasi. Medan: Yayasan Kita Menulis, 2020.

[12] J. Karim, "Sistem Pendukung Keputusan Penentuan Prioritas Pembangunan Menggunakan Metode Promethee Pada Desa Ayula Kecamatan Randangan Kabupaten Pohuwato Provinsi Gorontalo,” Ilk. J. Ilm., vol. 10, no. April, pp. 86-91, 2018. 